\title{
Estimation of Urinary Unconjugated Androstenedione, Dehydroepiandrosterone, Testosterone, Cortisol, Aldosterone and 18-Hydroxycorticosterone as a Potential Tool for Assessing Adrenal Status
}

\author{
By M. Schöneshöfer and B. Weber
}

Institute of Clinical Chemistry and Clinical Biochemistry

(Director: Prof. Dr. H. J. Dulce), Klinikum Steglitz der Freien Universität Berlin

(Received July 26/November 27,1982 )

\begin{abstract}
Summary: A method is decribed for the simultaneous assay of non-conjugated androstenedione, dehydroepiandrosterone, testosterone, cortisol, aldosterone and 18-hydroxycorticosterone in urine. The method involves solid-phase extraction, automatic high performance liquid chromatography and subsequent radioimmunological quantitation of the individual steroids. Excretion rates of these urinary free steroids were determined in normal males and females. There were no significant sex differences in excretion rates, although both urinary free testosterone and dehydroepiandrosterone were distinctly lower in females than in males. Representative measurements of the excretion rates of patients with Cushing's disease, Addison's disease, ectopic corticotropin syndrome and hirsutism were made. The present method has been shown to be well suited for routine purposes. Its final diagnostic significance for monitoring alterations in glucocorticoid, mineralocorticoid and androgenic activity of the adrenal cortex has yet to be explored.
\end{abstract}

Die Bestimmung von "freiem" Androstendion, Dehydroepiandrosteron, Testosteron, Cortisol, Aldosteron und 18-Hydroxycorticosteron im Harn als potentielle Laboratoriumsmethode zur Testung des Nebennierenrindenstatus

Zusammenfassung: Es wird eine Methode beschrieben, die die simultane Bestimmung der nicht-metabolisierten, nicht-konjugierten Fraktion der Steroide Androstendion, Dehydroepiandrosteron, Testosteron, Cortisol, Aldosteron und 18-Hydroxycorticosteron im Harn ermöglicht. Die Methode selbst setzt sich aus einer Festphasenextraktion, einer hochleistungsflüssigkeitschromatographischen Auftrennung und einer radioimmunologischen Endpunktbestimmung zusammen. Exkretionsraten der Steroide wurden bei normalen Männern und Frauen bestimmt. Es wurden keine signifikanten Geschlechtsunterschiede beobachtet, obwohl "freies" Testosteron und Dehydroepiandrosteron bei Frauen deutlich niedriger waren als bei Männern. Weiterhin wurden die Exkretionsraten bei Cushing- und Addison-Patienten, sowie bei Patienten mit ektopischem Corticotropin-Syndrom und Hirsutismus bestimmt. Die Methode erweist sich als geeignet für den Einsatz in der Routine. Der endgültige Stellenwert in der Diagnostik von Störungen der glukocorticoiden, der mineralocorticoiden und der androgenen Funktion der Nebennierenrinde bedarf allerding noch weiterer, klinischer Untersuchungen.

\section{Introduction}

It is generally accepted that the biological activity of steroid hormones in serum is more closely related to the non-protein-bound fraction than to the total se- rum steroid level $(1-3)$, and that serum levels of adrenal steroid hormones are strongly subject to diurnal and especially episodic variations (4-6). For screening purposes, the estimation of total adrenal 
steroid levels from single serum samples is therefore of dubious diagnostic value in assessing adrenal function. This lack of diagnostic validity might be overcome by the estimation of the excretion rates of non-metabolized, non-conjugated (free) steroid fractions in urine; e.g. urinary free cortisol (7) has been shown to correlate with the unbound fraction in serum and to integrate periodic fluctuations.

In fact, the use of urinary free cortisol as an index of adrenal function has now been used successfully in clinical practice for several years (8). Similarly, it has recently been demonstrated that urinary free aldosterone and 18-hydroxycorticosterone adequately reflect mineralocorticoid function (9). The findings on the importance of urinary free androstenedione and testosterone for monitoring androgenic states are contradictory $(10,11)$. To a great extent, the methodological problems inherent in the specific estimation of these low-concentration urinary free fractions may account for the slowness with which urinary free fractions have become accessible to the routine laboratory.

In the present paper we describe a method suitable for routine use which has been evolved to measure simultaneously the urinary free fractions of cortisol as an index of adrenal glucocorticoid activity, of aldosterone and 18-hydroxycorticosterone as indices of adrenal mineralocorticoid activity, and of androstenedione, dehydroepiandrosterone and testosterone as indices of the androgenic activity of either the adrenal cortex or/and the ovaries in females. Excretion rates are reported for four patients with clinically described Addison's disease, ectopic corticotropin syndrome, Cushing's disease and hirsutism.

\section{Materials and Methods}

\section{Urine specimen}

Twenty-four-hour urine samples were collected without preservatives, refrigerated at $4^{\circ} \mathrm{C}$ during collection and stored frozen until analysis.

\section{Subjects}

The normal groups of both sexes were healthy individuals from the hospital staff or medical students, males aged 24-35 years and females aged $21-33$ years, all within the first 10 days of the follicular phase of the menstrual cycle. All subjects were maintained on a free diet. All medications of the subjects were discontinued at least 24 hours before the urine collection period.

The diagnosis of the four patients studied had been substantiated clinically and biochemically.

Chemicals

Reagents such as organic solvents, labelled and unlabelled steroids, buffer solutions, radioimmunoassay (RIA) components and the antisera against cortisol, aldosterone and 18-hydroxycortico- steronc have been listed in previously published papers $(12,13)$. The antisera against androstencdione, testosterone and dehydroepiandrosterone were raised in rabbits by immunization with antigens coupled at C-3 (androstendione and dehydroepiandrosterone) or C-11 (testosterone) to bovine serum albumin. Crossreactivities of these antisera against related steroid molecules will be reported elsewhere (14).

Instrumentation

A Hewlett-Packard high performance liquid chromatograph (model $1084 \mathrm{~B}$ ) was used for automatic high performance liquid chromatography (HPLC). The instrumental accessories providing automatic operation from the sampling step to the fractionated collection of the steroid-containing fractions have been described previously (12). A polar coated silica (DIOL ${ }^{\circledR}$ Knauer Ltd., FRG) was used as the stationary phase, and $n$-hexane/isopropanol as the mobile phase run in a gradient mode $(12) .{ }^{3} \mathrm{H}$ radioactivity was measured in a liquid scintillation spectrometer (Packard Instr. model 2480).

\section{Methods}

In principle, the protocol of the assay followed the schedule outlined for the estimation of multiple steroids in human serum (12) and urine (14). Briefly, $1 \mathrm{ml}$ of urine labelled with tritiated isotope of each steroid was extracted with diethylether using the solid-phase Extrelut ${ }^{\circledR}$ technique. The evapored, organic extract was redissolved in $150 \mu$ l of the mobile phase and subjected to HPLC. Fractions containing steroids were automatically collectéd, evaporated and finally quantitated by RIA. Evaluation of the data was performed with a computer program using "spline approximation" as the standard curve model. Minute amounts of tritiated steroids occurring in the steroid fractions were taken into account in the final calculation.

\section{Results}

\section{Extraction}

The efficiency of the solid-phase extraction step was more than $95 \%$ for all steroids checked with ${ }^{3} \mathrm{H}$ recovery measurements.

\section{High performance liquid chromatography}

Figure 1a illustrates the UV-chromatogram of a standard mixture of the steroids to be assayed. The chromatographic parameters of the present HPLC system, such as retention times, capacity ratios and resolution between adjacent steroids, have already been documented in the serum steroid assay (12). The reproducibility of retention times, an essential parameter for the fractionation of the individual steroids, was quite good, with a coefficient of variation less than $1 \%$. The UV-chromatogram of a normal urine sample is shown in figure $1 \mathrm{~b}$; it demonstrates that considerable amounts of unspecific UV-absorbing compounds were eluted in the area of the steroids of interest. The recovery fractions of ${ }^{3} \mathrm{H}-\mathrm{la}$ belled steroids after HPLC ranged from 0.478 for 18-hydroxycorticosterone to 0.693 for androstendione. 'The memory effect was less than $0.5 \%$ when checked with ${ }^{3} \mathrm{H}$ radioactivity measurements. 


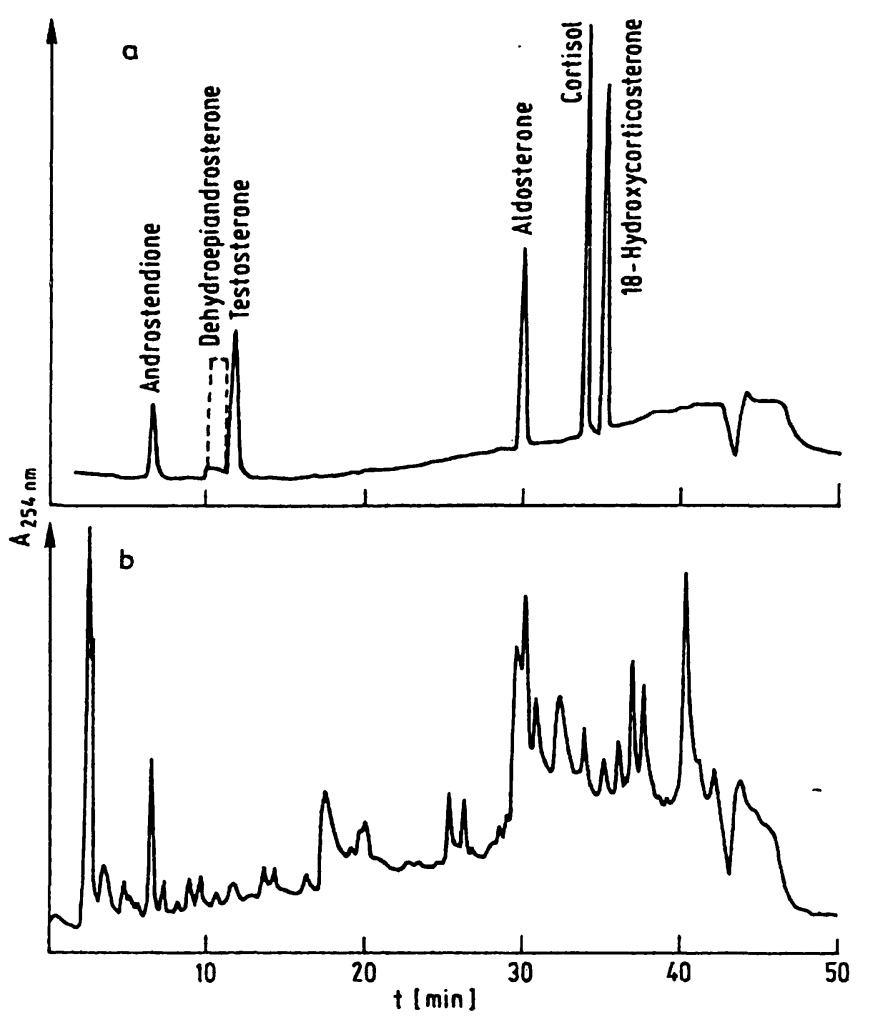

Fig. 1. HPLC chromatogram of a mixture of steroid standards (a) and of the ether extract of a normal urine sample (b). Dehydroepiandrosterone not detectable by UV-absorption was located by ${ }^{3} \mathrm{H}$ radioactivity measurement in $1 \mathrm{~min}$ fractions (dotted line).

\section{Analytical variables}

\section{Sensitivity}

The theoretical sensitivities (in $\mathrm{nmol} / \mathrm{l}$ ) of the total assay were calculated from the sensitivity of the particular standard curves ( 2 standard deviations of zero bound), from the aliquots for RIA and recovery measurements, and from the average factors of the procedural recoveries. The corresponding values ranged from $0.03 \mathrm{nmol} / 1$ for testosterone to 4.3 $\mathrm{nmol} / \mathrm{l}$ for cortisol. For the steroids androstendione, testosterone, aldosterone and 18-hydroxycorticosterone, the water blanks were slightly higher than the theoretical sensitivity, obviously due to unspecific immunologic interference. Charcoal-stripped urine blanks were comparable to water blanks.

\section{Specificity}

In addition to the study of cross-reactivities $(12,14)$, the degree of immunological interference arising from compounds present in the organic extracts of normal urine specimens was studied by measuring the steroid immunoreactivities in fractions eluted by HPLC (fig. 2). As already demonstrated for serum (12), it is evident that considerable unspecific immu- noreactivities are present in normal urine which are not attributable to steroids commonly studied for cross-reactivity. The present HPLC system, however, provides distinct separation of the steroids of interest from these unknown immunologically interfering substances.

\section{Precision, accuracy and practicability}

Intra-assay and interassay variability were studied by replicate measurements of normal urine samples. Coefficients of variation are listed in columns 1 and 2 of table 1. To date, 290 urine samples have been studied by this method. Accuracy was studied by correlating five different amounts of steroids added to a low-concentration urine sample with those found by the present method. Corresponding data from regression analyses are listed in columns 3 to 5 in table 1. As to practicability, the automatic mode of HPLC with overnight operation makes the present method quite suitable for routine purposes. About 40 samples can be extracted and chromatographed by unattended HPLC within two working days, during which time the radioimmunoassays of other batches can be processed.

Tab. 1. Precision and accuracy of total steroid assays. Equation of regression for accuracy: (Found) $=a_{0}+b x$ (added). $r=$ coefficient of correlation.

\begin{tabular}{|c|c|c|c|c|c|}
\hline Steroid & $\begin{array}{l}\text { Intra-assay } \\
\text { variation } \\
\mathrm{CV}(\%) \\
\mathrm{N}=10\end{array}$ & $\begin{array}{l}\text { Inter-assay } \\
\text { variation } \\
\mathrm{CV}(\%) \\
\mathrm{N}=4\end{array}$ & $\begin{array}{l}\text { Accuracy } \\
\mathrm{a}_{\mathrm{o}} \\
(\mathrm{nmol} / \mathrm{)})\end{array}$ & b & $r$ \\
\hline $\begin{array}{l}\text { Andro- } \\
\text { stendione }\end{array}$ & 4.7 & 15.9 & 0.09 & 1.10 & 0.998 \\
\hline $\begin{array}{l}\text { Dehydroepi- } \\
\text { androsterone }\end{array}$ & 6.9 & 9.9 & -0.068 & 1.16 & 0.999 \\
\hline Testosterone & 7.2 & 14.2 & 0.16 & 0.96 & 0.999 \\
\hline Cortisol & 6.1 & 20.2 & -0.51 & 1.18 & 0.996 \\
\hline Aldosterone & 9.4 & 13.5 & -0.068 & 1.16 & 0.998 \\
\hline $\begin{array}{l}\text { 18-Hydroxy- } \\
\text { corticosterone }\end{array}$ & 15.9 & 19.2 & -0.60 & 0.961 & 0.995 \\
\hline
\end{tabular}

Ranges in normal subjects and values in pathologic states

The excretion rates of the urinary free steroids were estimated in series from 23 normal males and 18 normal females. Absolute median values as well as upper and lower limits are listed in table 2. The data were evaluated according to a logarithmic distribution (15). In the female patient with Addison's disease, the urinary excretion rates of all steroids stu- 

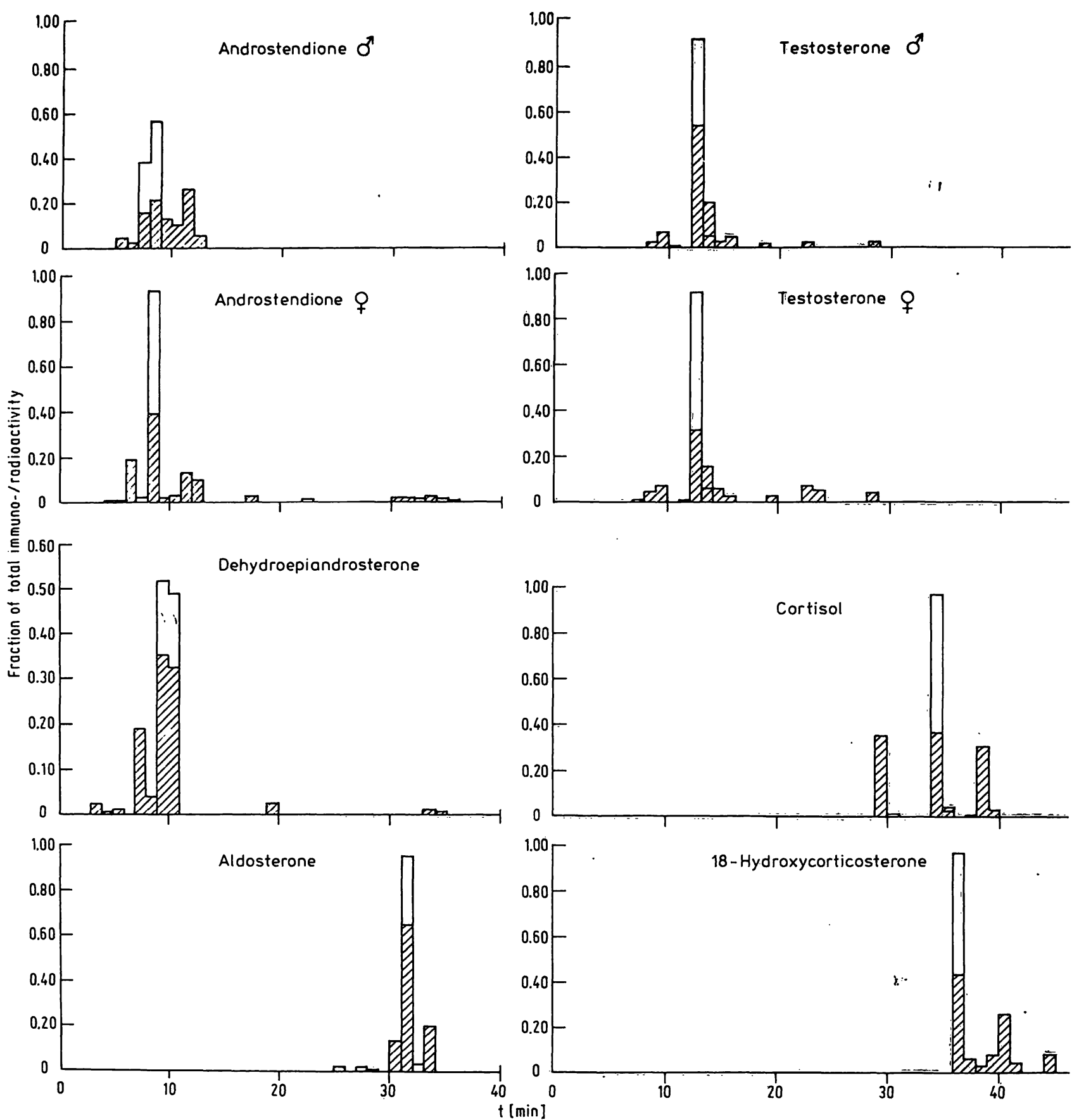

Fig. 2. Profiles of immunoreactivity (hatched area) and ${ }^{3} \mathrm{H}$ steroid radioactivity (open area) arising in 1 min HPLC fractions of the ether extracts of normal urine samples. Profiles for androstenedione and testostcrone were studied in female and male urine samples.

died were lower than the overall detection limits of the assay, thus indirectly documenting the adrenal source of all these steroids. With the exception of aldosterone, the excretion rates of all the steroids were more or less elevated in a female patient with hirsutism due to an adrenal adenoma. In the male patients with Cushing's disease and the ectopic corticotropin syndrome, excretion rates of androstenedione, dehydroepiandrosterone and cortisol were highly elevated. Testosterone was highly elevated only in the patient with ectopic corticotropin syndrome, whereas it was normal in the patient with Cushing's disease. In both patients, aldosterone and 18-hydroxycorticosterone were within the normal range.

\section{Discussion}

The data on the analytical parameters indicate that the present method for the simultaneous estimation of the unconjugated, non-metabolized steroids androstendione, dehydroepiandrosterone, testosterone, cortisol, aldosterone and 18-hydroxycorticosterone in urine is sufficiently reproducible, accurate, sensitive and specific. In particular, the data from the study on unspecific immunoreactivities present in the organic extract of a normal urine specimen (fig. 2) clearly underscore the necéssity, not only of an organic extraction of steroids from urine, but also of a high-resolution chromatographic purification step, if specific estimation is to be guaranteed. 
Tab. 2. Ranges for urinary unconjugated steroids in 18 healthy females (follicular phase) and 23 healthy males.

\begin{tabular}{|c|c|c|c|c|}
\hline Steroid & & $\begin{array}{l}\text { Lower limit } \\
(\mathrm{nmol} / 24 \mathrm{~h})\end{array}$ & $\begin{array}{l}\text { Median } \\
\text { (nmol/24 h) }\end{array}$ & $\begin{array}{l}\text { Upper limit } \\
(\mathrm{nmol} / 24 \mathrm{~h})\end{array}$ \\
\hline Androstenedione & $\begin{array}{l}\delta \\
q\end{array}$ & $\begin{array}{l}4.55 \\
3.26\end{array}$ & $\begin{array}{l}9.76 \\
6.89\end{array}$ & $\begin{array}{l}20.9 \\
14.56\end{array}$ \\
\hline $\begin{array}{l}\text { Dehydroepi- } \\
\text { androsterone }\end{array}$ & $\begin{array}{l}\delta \\
q\end{array}$ & $\begin{array}{l}2.69 \\
1.13\end{array}$ & $\begin{array}{r}6.76 \\
22.86\end{array}$ & $\begin{array}{r}16.97 \\
7.25\end{array}$ \\
\hline Testosterone & $\begin{array}{l}\delta \\
q\end{array}$ & $\begin{array}{l}0.65 \\
0.20\end{array}$ & $\begin{array}{l}1.43 \\
0.43\end{array}$ & $\begin{array}{l}3.16 \\
0.92\end{array}$ \\
\hline Cortisol & $\begin{array}{l}\delta \\
q\end{array}$ & $\begin{array}{l}39.5 \\
36.8\end{array}$ & $\begin{array}{l}56.5 \\
60.2\end{array}$ & $\begin{array}{l}80.7 \\
98.8\end{array}$ \\
\hline Aldosterone & $\begin{array}{l}\text { o } \\
\text { q }\end{array}$ & $\begin{array}{l}0.29 \\
0.30\end{array}$ & $\begin{array}{l}0.46 \\
0.51\end{array}$ & $\begin{array}{l}0.74 \\
0.86\end{array}$ \\
\hline $\begin{array}{l}\text { 18-Hydroxy- } \\
\text { corticosterone }\end{array}$ & $\begin{array}{l}\delta \\
q\end{array}$ & $\begin{array}{l}3.62 \\
3.51\end{array}$ & $\begin{array}{l}5.42 \\
5.41\end{array}$ & $\begin{array}{l}8.10 \\
8.33\end{array}$ \\
\hline
\end{tabular}

As already outlined for the estimation of serum steroids (12), this chromatographic requirement is successfully met by the HPLC technique described. The most prominent feature of the present purification method - in comparison to other chromatographic techniques - is the ability of HPLC to operate completely automatically.

As far as we have been able to ascertain, the reference ranges for urinary steroids found with the present method are comparable or slightly lower than those previously described in the literature $(8,10$, $11,13,14,16-18)$. Corresponding data on the excretion of urinary unconjugated dehydroepiandrosterone have not been documented so far. No significant differences between the sexes were found for the excretion rates of any of the steroids studied. These findings - particularly surprising for the excretion of urinary unconjugated testosterone - are

\section{References}

1. Angeli, A., Frajria, R., Crosazzo, C., Rigoli, F., Gaidano, G. \& Ceresa, F. (1979) In: The endocrine function of the human adrenal cortex. (James, V. H. T., Serio, M.. Giusti, G. \& Martini, L., eds.). London-New York: Academic Press, pp. $155-178$.

2. Vermeulen, A., Stoica, T. \& Verdonck, L. (1971) J. Clin. Endocrinol. Metab. 33, 759-767.

3. Anderson, D. C. (1974) Clin. Endocrinol. 3, 69-96.

4. Hellman, L., Nikada, F., Curti, J., Weitzman, E. D., Kream, J., Roffwarg, H., Ellman, S., Fukushima, D. K. \& Galagher, T. G. (1970) J. Clin. Endocrinol. Metab. 30, 411-421. in agreement (so far as data are available) with findings in the literature $(10,11,19)$. In contrast to testosterone, dehydroepiandrosterone is predominantly of adrenal origin (20) and thus would be expected if related to serum concentration - to be independent of sex. The fact that urinary excretion of unconjugated dehydroepiandrosterone is distinctly (tab. 2), although not significantly, lower in females than in males indicates that the urinary unconjugated non-metabolized fraction of steroids does not necessarily reflect serum steroid levels, and that the finding of a linear renal clearance of unconjugated cortisol (7) cannot simply be extrapolated to the other steroids. This conclusion is also supported by the considerable overlapping of urinary excretion rates of testosterone in males and females $(10,11,19)$, although serum testosterone levels are characterized by distinct and significant sex differences (21). These findings are probably accounted for by the degree of binding to specific serum proteins or by sex-dependent processes occurring in hepatic and, in particular, in renal steroid metabolism, such as glomerular filtration, tubular reabsorption and re-excretion. They must be the subject of further investigations.

Concerning the diagnostic significance of the urinary free steroids in monitoring alterations in mineralocorticoid, glucocorticoid and androgenic states, the clinical cases available to us at this time do not suffice to conclusively establish their usefulness. Further studies, especially on physiological and pharmacological factors influencing renal metabolism of these steroids, and on correlations between excretion rates and clinical symptomatology or pathologic states, are needed to substantiate their final diagnostic significance.

\section{Acknowledgements}

We gratefully acknowledge the provision of computer facilities in the Department of Radiology by Prof. Dr. Koeppe, and the generous gift of aldosterone antibody by the National Institutes of Health, Bethesda, MD, U.S.A.
5. Lincoln, G. A., Rowe, P. H. \& Racey, R. A. (1974) In: Chronobiological aspects of endocrinology (Aschoff, J.. Cercsa. F. \& Halber, G., eds.). Stuttgart: Schattauer Verlag, pp. 137152.

6. Kage, A., Fenner, A., Weber, B. \& Schöneshöfer, M. (1982) Klin. Wochenschr. 60, 659-666.

7. Beisel, R. R., Cos, J. J., Horton, R., Chao. P. Y. \& Forshan. P. H. (1964) J. Clin. Endocrinol. Metah. 24. 887-893.

8. Burke, C. W. \& Beardwell, C. G. (1973) Quart. J. Med. 42, $175-204$. 
9. Ammenti, A., Mueller-Wiefel, D. E., Schaerer, K. \& Vecsei, P. (1980) Clin. Nephrol. 14, 238-245.

10. Andino, N., James, V.H.T., Parker, V. \& Rippon, A.E. (1976) Steroids 28, 837-846.

11. Kjeld, J. M., Puah, C. M. \& Joplin, G. F. (1977) Clin. Chim. Acta $80,271-284$.

12. Schöneshöfer, M., Fenner, A. \& Dulce, H. J. (1980) J. Steroid Biochem. 14, 377-386.

13. Schöneshöfer, M., Fenner, A., Altinok, G. \& Dulce, H. J. (1980) Clin. Chim. Acta 106, 63-73.

14. Schöneshöfer, M. \& Weber, B. (1983) J. Steroid Biochem. 18, 65-73.

15. Sachs, L. (1974) Angewandte Statistik. Berlin-HeidelbergNew York: Springer Verlag, pp. 86-89.

16. Connolly, T. M.. Vecsei, P., Haack, D., Kohl, K. H., Abdelhamid. S. \& Ammenti, A. (1978) Klin. Wochenschr. 56 (Suppl. I) 173-181.
17. Deck, K. A., Champoin, P.KK. \& Conṇ, J. W. (1973) J. Clin. Endocrinol. Metab. 36, 756-760.

18. Hubl, W., Stahl, F., Büchner, M. \& Garten, C. D. (1976) Endokrinologie 68, 283-291.

19. Stahl, F., Dörner, G., Poppe, I., Rohde, W., Knappe, G., Stober, B. \& Raabe; B. (1974) Endokrinologie 64, 63--73

20. Genazzani, A. R., Peciarini-Suickars, L., Franchi, F., de Leo, V., Picciolini, E. \& Tarascio, P. (1978): Hormone Res. 9 379-393.

21. Vermeulen, A. (1979) In: Hormones in blood (Gray, C. H. \& James, V. H. T., eds.). London-New York: Academic Press, pp. 356-416.

Prof. Dr. Dr. M. Schöneshöfer

Klinikum Charlottenburg.

Klinisch-chemisches Zentrallabor

Freie Universität Berlin

Spandauer Damm 130

D-1000 Berlin 19 